\title{
Do Muslim Donors Consider Accountability, Trust, and Reputation?
}

\author{
Wahyu Adji Nur Ridho ${ }^{1}$, Evony Silvino Violita ${ }^{2}$ \\ \{wahyu.adji.nr@gmail.com ${ }^{1}$, evony.silvino@gmail.com ${ }^{2}$ \} \\ ${ }^{1}$ Islamic Business, Universitas Indonesia, Depok, Indonesia \\ Corrsesponding Author: ${ }^{2}$ Department of Acconting, Universitas Indonesia, Depok, Indonesia
}

\begin{abstract}
In Islamic philanthropy sector, especially, the charitable sector called ziswaf (zakat, infaq, sadaqah, and waqf), increasing accountability is believed to be able to increase trust, reputation, and even a solution to increase donation as well. However, it is still lack of empirical evidence whether muslim donors do consider accountability of ziswaf institution. This is a quanitative study aimed to see the effect of accountability level to public trust, reputation, and donation. Data obtained from experiment of 158 muslim middle-income class respondents from Jabodetabek. Experiment is done online by providing five fictive cases based on five accountability level, from the lowest institution with no accountability to the highest institution with external accountability and accreditation. Respondents were illustrated within one of the cases and then they were asked about trust, reputation, and donation to the illustrated institution. Data analysis is done using SEM-PLS with the results validate the view that accountability affects trust and reputation. Donation revenue is affected by accountability only through mediation of reputation. Along with accountability, it is also clear that reputation has important role in increasing trust and donation.
\end{abstract}

Keywords: Accountability, Public Trust, Reputation, Donation, Ziswaf.

\section{Introduction}

In Indonesia, low level of accountability is indicated to be one of the obstacles in reaching potential amount of ziswaf funds. According to the Indonesian Waqf Board (BWI), the potential for wakaf money to be realized is only $0.2 \%$ of Rp180 trillion [1]. While zakat recorded in the official zakat collection unit is only about $1 \%$ of the Rp286 trillion potential for zakat funds in Indonesia [2]. Among the causes of this problem that are often cited are low public trust, transparency issues, and professionalism of ziswaf institutions [3][4][5][6]. In other words, ziswaf institutions must be able to show their trustworthiness (amanah) and reliability.

\section{Literature Review and Hypotheses Development}

Back to history of nonprofit sector, one of the main factor due to its emergence is the nondistribution constraints basis [7]. Hannsman (1987) in DiMaggio \& Annheier, (1990) stated that there were certain transactions, or provision of some services which are only ethical if done in nonprofit way, where the owners of that instution are not seeking profit for themselves (non-distribution constraint) [8]. This made public see those non-profit organizations are trustworthy by its nature, compared to profit-seeking organizations. However, many issues and scandals later emerged, such as fraud, misappropriation of funds, inflated operational budget, and suspicious affiliation with companies, that prevented nonprofit institutions from gaining public trust only with non-distribution capital constraints, and thus they had to pay attention to accountability [9][10][11].

There are literatures done explaining the urgency of accountability to donations in charitable organizations. However, this paper attempt to explain the role of accountability and other adjacent factors on how they will affect donation. 


\subsection{Accountability}

Conceptually, accountability is a individual and organizational form to account for its measured performance in the most objective way possible [12]. Accountability arises from agency theory, and thus it is about responsibility to stakeholders [13].The agency problem in nonprofits creates risks in the eyes of donors, and this risk prevents someone from donating. [14].

Donors face the risk that funds will not be donated, or the management may not be as expected by donors. Thus, if the institution's accountability is getting better, the risk faced by donors will be lower, so that donors will be more confident with the agency to donate. Slatten et. al (2011) explains that the existence of accreditation, or assessment from outside, can reduce this risk thereby increasing donations received by non-profit organizations [14]. It is found that nonprofits that adhere to certain accountability standards attract more donations than those who do not [15]. While in Indonesia, it is found that the level of accountability had a positive effect on the receipt of zakat [16][17].

H1: Accountability level of Islamic NPO direclty and positively influences donation

\subsection{Trust}

Trust is a psychological condition that consists of intention to accept vulnerability based on positive expectations of the intentions or behavior of others [18]. There are types of trust, but specifically institutional trust in non-profit organizations in general has positive effect in encouraging someone to donate [15][19].

Charity institutions can increase the trust of its donors by increasing the information exposure and experience of the donor for what the institution has done in carrying out its mission [20]. Cases of fraud deny the trustworthiness signals of this sector, so that nondistrubution constraints are doubtful in shaping public trust [21]. When the power of this unique characteristics of nonprofit sectors is doubtful, increasing accountability is relevant in overcoming trust issues [14][22][23].

Therefore, accountability provides trust signals as information that is processed by donors in growing trust to the institution (or so-called institutional trust). This is proven with findings by Hasrina (2018) and Becker (2018) [24][25]. An organization with high level accountability, (for example, having audited financial report) certainly has better signal of trustworthiness signal than the one which do not prepare any financial report. If the institution's accountability is good, it can increase public trust in it.

H2: Accountability level of Islamic NPO positively influences trust

Trust is a determining factor for someone to donate, because donations in large amount of money make donors need trust in their decision making, whether the institution will actually do what is promised to donors [26]. Thus, donors will feet reassured to distribute their donations to those who are trusted than those who are not. From many previous studies such as Bekkers (2003) and Burnnet (2002) that a high level of trust in charity-based nonprofits is associated with a high desire to become a donor and make greater donations [22][27]. Even Sargeant \& Lee (2002) found that around 13\% R2 of a person's donation is explained by their level of trust [20]. Evers \& Gesthuizen (2011) and Janssen (2016) find that trust in institutions has a significant positive relationship with donations [19][28]. Fahmi \& Nur (2019) found that trust in zakat institutions significantly influenced respondents' interest in zakat [29]. Sargeant \& Lee (2004) found that there is a positive correlation of trust on donation behavior, directly or through 
mediation of commitment. Therefore, it is hypothesized that there is influence of the level of trust in the behavior of donations, but not on small donation.

\section{H3: Trust positively influences donation}

\subsection{Reputation}

Reputation is understood as an overall evaluation by various stakeholders [30]. In theory, reputation is an important factor for a service company, because services are intangible products [31]. Thus, for non-profit organizations whose products are intangible, and not even consumed by donors, reputation is important [32].

The donor's assessment of an institution depends on the information he gets and how the level of accountability of an institution can shape reputation. Willems et. al (2017) and Bies (2010) in Becker (2018) explain that the accountability of voluntary non-profit institutions (such as certification from outsiders) results in higher legitimacy and better reputation [25]. Khaerany (2013) found that the level of accountability has a positive influence on one aspect of reputation, which is quality [33].

H4: Accountability level of Islamic NPO positively influences reputation

Reputation also affects trust, because if an institution has a bad reputation, donors do not give credence to it [34]. Thus, the cause of donors to trust an institution is based on an assessment of its reputation. Giffin (1967) in Mayer (1995) states that among the determinants of a person's trust in something is reputation [34]. Entrusting someone to do something is influenced by his reputation in doing so. Torres-Moraga et al. (2014) found that institutional trust was significantly influenced by the institution's reputation [20]. Likewise, at online trading transactions where both parties have minimal information, the trust of prospective buyers is built on the reputation of the seller [35].

H5: Reputation positively influences trust

Reputation is an important handle for donors in their donation decisions. This is because the characteristic of a non-profit institution is that its products are intangible, so it will be difficult for consumers to determine whether the donor has taken good ziswaf management services or not. In tangible products, consumers will easily judge whether the product is good or not and how much is its value, while such things cannot be found in intangible service products offered by non-profit institutions. Therefore, reputation is an important factor assessed by consumers of ziswaf institutions (donors), and thus donors will tend to prefer donating to nonprofit institutions with a higher reputation. This logic is supported by Snipes \& Olwald (2010) who found that the reputation of nonprofits is a major factor in decision making for donors [35]. Meijer (2009) has found that reputation has a positive effect on increasing the number of donors, but, does not get enough evidence to say reputation influences the number of donations received [33]. Mews \& Boenigk (2013) found that if a charity changed its reputation declined, it would have a significant impact on reducing donor intentions in the case of blood donations [36].

H6: Reputation positively influences donation.

\subsection{Reputation and Trust as Mediating Variable}

Donors may not necessarily be motivated to donate only because of institutional information about their accountability. It is possible that accountability is the basis of donors in shaping a reputation and then encouraging donations. This is because having information related to institutional accountability might be more complicated to encourage donations, whereas if the accountability information is processed to form a reputation then the information becomes a simpler and clearer figure to the product quality assessment process. 
Discussions about non-profit institutions' reputation as variables which simplify accountability information that affect consumer behavior are still minimal. However, it was found that in the context of aviation services, that consumers' willingness to pay is influenced by information about organizational characteristics mediated by the company's reputation [37]. The research revealed that consumers are not directly motivated by the formative aspects of company characteristics, but it does affect the reputation and thus affects the willingness to pay by consumers. Thus, the company is not just looking for aspects of the company's characteristics (the level of accountability in the context of this study) but also the overall reputational factor. H7: Accountability level of Islamic NPO positively influence donation through reputation.

If the perception of risk (the risk of misuse of funds) faced by a donor is a barrier to donors in donating to a ziswaf institution, then the way to increase donations is to increase trust. Since the level of accountability influences donor trust in the institution, accountability plays a role in minimizing risk [11]. Thus, increasing accountability will be able to increase donations, not directly, but through mediation to increase trust. If trust is not a problem in donating, increasing accountability may not affect donations. The discussion of trust as a mediator that influences behavior is found in online purchase intentions by Chang \& Chen (2008). In his research, it was found that among those that prevented the public from purchasing products online was risk perception (fear of fraud), and trust in shopping sites was one of the determinants of purchase intentions because it was closely related to risk perception. How the look and feel of a shopping site affect purchase intentions is mediated by trust [38].

H8: Accountability level of Islamic NPO positively influence donation through trust.

\section{Methods}

This study seeks to prove that accountability has a role in increasing donations, both directly, and by mediating by trust and reputation. In summary, this research model is as follows.

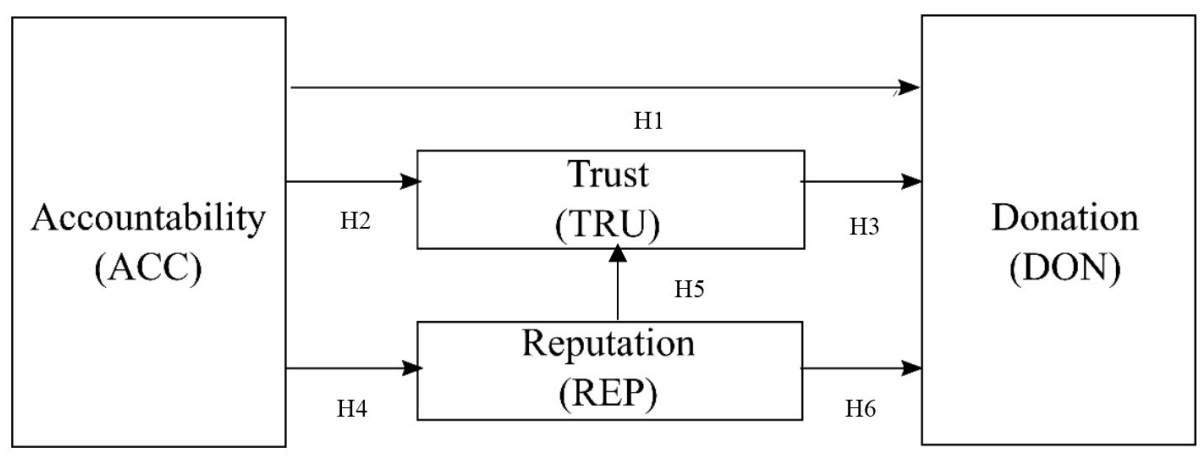

H7: $\mathrm{ACC}>\mathrm{DON}$ (through Reputation as mediating variable)

$\mathrm{H} 8$ : ACC $->$ DON (through Trust as mediating variable)

Figure 1. Research Model

This research was conducted online by showing illustration to the respondents and then they were asked to fill a questionnaire. This positioned respondents as winning a prize of Rp500.000 (12.5\% of the regional minimum wage) and had the opportunity to donate to a real Islamic charitable/ziswaf institution, with its identity and the level of accountability of the ziswaf institution described within the illustration. There are five illustrations correspond with five level of accountability of ziswaf institutions in Indonesia (No accountability, legal 
minimum as foundation, internal voluntary accountability, external accountability as official ziswaf institution, and external accountability with good accreditation by the government). The identity of this institution taken from a real ziswaf institution namely its vision and mission as well as the field it undertakes, and its name is disguised as Baitus Sadaqah (House of Charity). It is intended that this vision and mission reflect a real non-profit ziswaf institution, while its name is disguised to avoid bias in reputation assessment or initial trust in the minds of respondents. It was stated that Baitus Sadaqah worked in the field of poverty, and according to Kasri (2013), the issue of poverty in the charity sector in Indonesia was among the most enthused issues [39].

Later they were asked about their level of trust, reputation, and the amount of donations for the institution. The donor segment of this study is limited to Muslims in Greater Jakarta who earn between the regional minimum wage and ten million rupiah per month (middle economic class).

\section{Discussions}

From more than 1000 questionnaire spread online, only quarter submitted back. Since this data collecting was done online, strict data screening and manipulation check are needed to make sure our respondents have read carefully and understand the accountability illustration. Only 158 of them are considered valid respondent, and this sample size is enough for method used in this research (PLS) [40].

The data received is then processed with PLS-SEM method using SmartPLS [41]. All variables passed the test for measurement model. The accountability variable is in the form of categorical variable and is processed as dummy with the lowest level of accountability being the basis.

Before discussing path coefficients of the model, please note that this model is fit based on Bollen-Stine Bootstrap [42]. SRMR value of 0.037, lower than the Bollen-Stine Bootstrap confidence interval of $95 \%$ by 0.038 and also lower than the general standard of SRMR 0.08 . Based on its $\mathrm{D}_{\mathrm{ULS}}(0.109)$ is also lower from the $95 \%$ confidence interval $(0.112)$.

This study found that there was no significant direct relationship between accountability and donations. However, accountability is proven to significantly influences trust and donations. In addition, the reputation variable appears to have very important role due to the significant relationship between reputation with donations and with trust also.

Table 2. Path Coefficient

\begin{tabular}{lllll}
\hline Hypotheses & Path & $\boldsymbol{\beta}$ & P-value & Conclusions \\
\hline H1 & Accountability $\rightarrow$ Donation & 0.044 & 0.354 & Not Significant \\
H2*** & Accountability $\rightarrow$ Trust & 0.206 & 0.002 & Highly Significant \\
H3 & Trust $\rightarrow$ Donation & 0.160 & 0.109 & Not Significant \\
H4*** & Accountability $\rightarrow$ Reputation & 0.627 & 0.000 & Highly Significant \\
H5*** & Reputation $\rightarrow$ Trust & 0.673 & 0.000 & Highly Significant \\
H6** & Reputation $\rightarrow$ Donation & 0.215 & 0.030 & Significant \\
\hline
\end{tabular}

The insignificant relationship between trust and donation is contrary with earlier researches. However, Awang et al (2017) also found the insignificant relationship between these two variables [43]. There might be some perspective in this result that it means a donor might be trust the explained institution, but this trust does not motivate them to donate more. It can 
also be seen that trusting an institution can be a requirement in donation, but level of trust does not correlate with the amount of donations given.

From the perspective of Muslim donors, there might be difference. If we get back to the earlier theories of trust, Macaulay (1963) in Rousseau et al (1998), someone does not necessarily to built trust on other party when the transaction is well structured and monitored [18]. Muslim donors' intention in giving charity is to get merits from Allah, to complete their religious obligation (zakat), or any other religious motives. If it is true, Muslim donors know that the merit they get is based on their purity of intentions within their heart, not the accomplishment of other party (the beneficiary or the ziswaf institution) [44]. Any bad deeds done by the other party, are monitored and retaliated by Allah [44]. From this perspective, Muslim donors' behavior might be different in their donation practices, but it is still needed to be researched further.

In mediation testing, it is can be seen that reputation variable is proven to be a positive mediator for accountability in influencing donations. Trust has no significant mediation effect, since its direct relationship with donation is also insignificant.

Table 3. Mediation Test

\begin{tabular}{|c|c|c|c|c|c|c|c|}
\hline Hypotheses & Path & B & $\begin{array}{l}\text { Indifect } \\
\text { Effects }\end{array}$ & $\begin{array}{l}\text { Std. } \\
\text { Dev. }\end{array}$ & $\begin{array}{l}\text { Total } \\
\text { Effect }\end{array}$ & VAF & P-val \\
\hline & Acc. $\rightarrow$ Don. & 0.044 & & & & & 0.354 \\
\hline $\mathbf{H} 7 * *$ & $\begin{array}{l}\text { Acc. } \rightarrow \text { Rep. } \\
\text { Ref } \rightarrow \text { Don. }\end{array}$ & $\begin{array}{l}0.627 \\
0.215\end{array}$ & 0.135 & 0.074 & \multirow{2}{*}{0.279} & $48 \%$ & 0.034 \\
\hline \multirow[t]{2}{*}{ H8 } & $\begin{array}{l}\text { Acc. } \rightarrow \text { Tru. } \\
\text { Tru. } \rightarrow \text { Don. }\end{array}$ & $\begin{array}{l}0.206 \\
0.160\end{array}$ & 0.033 & 0.031 & & $11 \%$ & 0.147 \\
\hline & $\begin{array}{c}\text { Acc. } \rightarrow \text { Ref. } \rightarrow \\
\text { Tru. } \rightarrow \text { Don. }\end{array}$ & - & 0.067 & 0.057 & & $24 \%$ & 0.120 \\
\hline
\end{tabular}

\section{Conclusions}

\subsection{Conclusions and Managerial Implications}

This study finds that accountability is proven to have a significant role in increasing trust and reputation. It is also found a significant relationship between reputation with the level of donations by which accountability can increase donations received indirectly, i.e. through reputation as mediating variable. Reputation also has another important role as one of forming trust. Thus, activities in increasing accountability which are also utilized in order to improve ziswaf institution's reputation will have positive impact on the public ziswaf institutions in the public and can also increase donations.

In order to increase donations from muslim donors, Islamic charitable organization (i.e. ziswaf institution) should increase accountability within the framework of increasing its overall reputation because reputation serves as a mediator between accountability for donations. This can be done by showing the accountability of the institution, whether the results of the audit of the ministry of religion, auditing public accountants, reporting the use of funds to muslim donors, or the results of development in the community (recipient of funds) for funds that have been managed so that the ziswaf institution looks accountable and reliable.

\subsection{Limitations and Suggestions for Further Research}

This research is done by online experiment, and thus there may be difference with donor's behavior while facing real condition. Donors attitude while facing a real Islamic charitable institutions with all of the marketing tools used to attract donors might resulting different 
behavior in donation giving and not limited to its accountability informations. This means there are factors in establishing Islamic charitable institutions' reputation other than accountability, and that is important to be studied further.

The amount of charity given might also be affected by donor's personal conditions (not the charitable institutions) like current financial condition and their generosity. Those could make predictive power of this model (in predicting amount of donation) rather small (the $\mathrm{R}^{2}$ is only $14 \%$ ). Although in consumer behavior studies, $20 \% \mathrm{R}^{2}$ is already considered as high.

Our research found that trust is insignificant (or not as strong as reputation) in influencing amount of donation. This, however, must be understood with caution. Further studies are needed to explain this irregular findings. Zakat (obligatory donation) and waqf (charitable endowment) are kinds of charity potential we are commonly talking about their potential. There are types of zakat which given periodically (annually). Waqf is a kind of donation for lasting assets. Those two donations necessitate longer relationship between donors and the ziswaf institutions, and thus different kind of trust is needed to be explained in this Islamic charitable giving behavior.

\section{References}

[1] A. Somov, "Wildfire safety with wireless sensor networks," ICST Trans. Ambient Syst., vol. 11, no. 10-12, pp. 1-11, 2011.

[2] Center of Strategic Studies - The National Board of Zakat, Indonesia Zakat Outlook 2019, no. December 2018. PUSKAS BAZNAS, 2019.

[3] A. Mukhlis and I. S. Beik, "Analisis Faktor-faktor yang Memengaruhi Tingkat Kepatuhan Membayar Zakat: Studi Kasus Kabupaten Bogor,” Al-Muzara'ah, vol. 1, no. 1, pp. 83-106, 2013.

[4] A. H. Daulay and I. Lubis, "Analisis Faktor-faktor Penyebab Keengganan Masyarakat Membayar Zakat Melalui Instansi BAZIS/LAZ di Kota Medan,” J. Ekon. dan Keuang., vol. 3, no. 3, pp. 242-251, 2015.

[5] M. Yuliani, D. Meliza, and F. Fitrianto, "Analisis Faktor-Faktor Penyebab Keengganan Masyarakat Membayar Zakat Melalui Baznas Kabupaten Kuantan Singingi,” J. Tabarru' Islam. Bank. Financ., vol. 1, no. 2, pp. 1-13, 2018.

[6] A. Rusydiana, Aam S; Devi, "Analisis Pengelolaan Dana Wakaf Uang di Indonesia: Pendekatan Metode Analytic Network Process (ANP)," Al-Awqaf J. Wakaf dan Ekon. Islam, vol. 10, no. 2, pp. 115-133, 2017.

[7] H. Hansmann, The Economic Role of Commercial Nonprofits: The Evolution of the Savings Bank Industry. Berlin: Walter de Gruyter \& Co, 1990.

[8] P. J. DiMaggio and H. K. Anheier, "The Sociology Of Nonprofit Organizations And Sectors," Annu. Rev. Sociol., vol. 16, no. 1, pp. 137-159, 1990.

[9] A. Sargeant, J. B. Ford, and D. C. West, "Perceptual determinants of nonprofit giving behavior,” J. Bus. Res., vol. 59, no. 2, pp. 155-165, 2006.

[10] J. Steffek and K. Hahn, Introduction: Transnational NGOs and Legitimacy, Accountability, Representation. London: Palgrave Macmillan, 2010.

[11] Q. Xue and Y. Niu, "Governance and transparancy of th Chinese charity foundations," Asian Rev. Account., vol. 27, no. 2, pp. 307-327, 2019.

[12] K. P. Kearns, "The Strategic Management of Accountability in Nonprofit Organizations: An Analystical Framework," Public Adm. Rev., vol. 54, no. 2, pp. 185192, 2013.

[13] A. Najam, "NGO Accountability: A Conceptual Framework," Dev. Policy Rev., vol. 14, pp. 339-353, 1996.

[14] L. A. D. Slatten, B. N. Guidry, and W. Austin, "Accreditation and certification in the 
non-profit sector: Organizational and economic implications," Organ. Manag. J., vol. 8, no. 2, pp. 112-127, 2011.

[15] R. Bekkers and P. Wiepking, A literature review of empirical studies of philanthropy: Eight mechanisms that drive charitable giving, vol. 40, no. 5. 2011.

[16] E. R. Wulan, W. Sari, and S. Setiawan, "Pengaruh Transparansi dan Akuntabilitas Pelaporan Keuangan terhadap Kinerja Keuangan Penerimaan Dana Zakat di Kota Bandung," in International Conference on Islam in Malay World (ICON IMAD) III, 2013.

[17] A.Zubaidah, "Pengaruh Transparansi dan Akuntabilitas Pengelolaan Zakat terhadap Minat Muzakki di Rumah Zakat Cabang Semarang," Institut Agama Islam Negeri Walisongo, 2014.

[18] D. M. Rousseau, S. B. Sitkin, R. S. Burt, and C. Camerer, "Not so different after all: A cross-discipline view of trust," Acad. Manag. Rev., vol. 23, no. 3, pp. 393-404, 1998.

[19] A. Evers and M. Gesthuizen, "The impact of generalized and institutional trust on donating to activist, leisure, and interest organizations: individual and contextual effects," Int. J. Nonprofit Volunt. Sect. Mark., vol. 16, no. 4, pp. 381-392, 2011.

[20] E. Torres-Moraga, A. Z. Vásquez-Parraga, and C. Barra, "Antecedents of donor trust in an emerging charity sector: The role of reputation, familiarity, opportunism and communication," Transylvanian Rev. Adm. Sci., vol. 6, no. 29 E, pp. 159-177, 2010.

[21] A. Prakash and M. K. Gugerty, "Trust but verify? Voluntary regulation programs in the nonprofit sector," Regul. Gov., vol. 4, no. 1, pp. 22-47, 2010.

[22] R. Bekkers, "Trust, Accreditation, and Philanthropy in the Netherlands," Nonprofit Volunt. Sect. Q., vol. 32, no. 4, pp. 596-615, 2003.

[23] A. Ebrahim, "The many faces of Nonprofit Accountability," in The Jossey-Bass Handbook of Nonprofit Leadership and Management, D. O. Renz and R. D. Herman, Eds. John Wiley \& Sons, Inc, 2010, pp. 102-123.

[24] C. D. Hasrina, Y. Yusri, and D. R. A. S. Sy, "Pengaruh Akuntabilitas dan Transparansi Lembaga Zakat Terhadap Tingkat Kepercayaan Muzakki Dalam Membayar Zakat Di Baitul Mal Kota Banda Aceh,” J. Hum. J. Ilmu Sos. Ekon. dan Huk., vol. 2, no. 1, pp. $1-9,2019$.

[25] A. Becker, "An Experimental Study of Voluntary Nonprofit Accountability and Effects on Public Trust, Reputation, Perceived Quality, and Donation Behavior," Nonprofit Volunt. Sect. Q., vol. 47, no. 3, pp. 562-582, 2018.

[26] R. A. Cnaan, K. Jones, A. Dickin, and M. Salomon, "Nonprofit Watchdogs Do They Serve the Average Donor?," Nonprofit Manag. Leadersh., vol. 21, no. 4, pp. 381-397, 2011.

[27] I. S. Alhidari, T. M. Veludo-De-Oliveira, S. Y. Yousafzai, and M. Yani-De-Soriano, "Modeling the Effect of Multidimensional Trust on Individual Monetary Donations to Charitable Organizations," Nonprofit Volunt. Sect. Q., vol. 47, no. 3, pp. 1-22, 2018.

[28] W. Janssen, "Trust and charitable behaviour: A study about the effects of trust on charitable behaviour in the Netherlands," Utrecht University, 2016.

[29] Zulfahmi and M. M. Nur, "Pengaruh Pengetahuan, Pendapatan, dan Kepercayaan, Terhadap Minat Muzakki Dalam Membayar Zakat di Baitul Mal Kota Lhokseumawe," J. Ekon. Reg. Unimal, vol. 1, no. 3, pp. 89-99, 2018.

[30] Sarstedt Marko and Schloderer Matthias Peter, "Developing a measurement approach for reputation of non-profit organizations," Int. J. Nonprofit Volunt. Sect. Mark., vol. 15, no. November 2009, pp. 276-299, 2010.

[31] R. Greenwood, S. X. Li, R. Prakash, and D. L. Deephouse, "Reputation, diversification, 
and organizational explanations of performance in professional service firms," Organ. Sci., vol. 16, no. 6, pp. 661-673, 2005.

[32] M. M. Meijer, "The effects of charity reputation on charitable giving," Corp. Reput. Rev., vol. 12, no. 1, pp. 33-42, 2009.

[33] R. Khaerany, "Akuntabilitas dan Transparansi Lembaga Pengelola Zakat Terhadap Kualitas Lembaga Amil Zakat (Pandangan Muzakki dan Amil Zakat pada Dompet Dhuafa Sulsel)," Hasanuddin University, 2013.

[34] R. C. Mayer, J. H. Davis, and F. D. Schoorman, "An Integrative Model of Organizational Trust," Acad. Manag., vol. 20, no. 3, pp. 709-734, 1995.

[35] R. L. Snipes and S. L. Oswald, "Charitable giving to not-for-profit organizations: factors affecting donations to non-profit organizations," Innov. Mark., vol. 6, no. 1, pp. 73-80, 2010.

[36] M. Mews and S. Boenigk, "Does organizational reputation influence the willingness to donate blood?," Int. Rev. Public Nonprofit Mark, vol. 10, no. 1, pp. 49-64, 2013.

[37] M. E. Graham and P. Bansal, "Consumers' Willingness to Pay for Corporate Reputation: The Context of Airline Companies," Corp. Reput. Rev., vol. 10, no. 3, pp. 189-200, 2007.

[38] H. H. Chang and S. W. Chen, "The impact of online store environment cues on purchase intention: Trust and perceived risk as a mediator," Online Inf. Rev., vol. 32, no. 6, pp. 818-841, 2008.

[39] R. A. Kasri, "Giving behaviors in Indonesia: Motives and marketing implications for Islamic charities," J. Islam. Mark., vol. 4, no. 3, pp. 306-324, 2013.

[40] D. S. Soper, "Post-hoc Statistical Power Calculator for Multiple Regression [Software]," http://www.danielsoper.com/statcalc, 2019. [Online]. Available: http://www.danielsoper.com/statcalc. [Accessed: 15-Apr-2019].

[41] C. M. Ringle, S. Wende, and J.-M. Becker, "SmartPLS 3," https://www.smartpls.com/, 2015. [Online]. Available: https://www.smartpls.com/. [Accessed: 15-Apr-2019].

[42] J. Henseler, G. Hubona, and P. A. Ray, "Using PLS path modeling in new technology research: Updated guidelines,” Ind. Manag. Data Syst., vol. 116, no. 1, pp. 2-20, 2016.

[43] A. Salwa Amirah, B. Joni Tamkin, M. Mohamad Taqiudin, and M. Fidlizan, "The Scenario Of Giving to beggars: A behavioural analysis among Malaysians," Labu. eJournal Muamalat Soc., vol. 11, pp. 39-50, 2017.

[44] S. S. bin I. Al Hilali, Bahjatun Nazhirin Syarh Riyadhish Shalihin. Pustaka Imam Syafii, 2000. 